\title{
Crianças Migrantes / Migrant Children
}

https://doi.org/10.21814/uminho.ed.36.19

Universidad Complutense de Madrid, España 



\section{Crianças Migrantes}

As crianças migrantes têm menos de 18 anos de idade e vivem numa região ou país distinto do seu local de nascimento, depois de atravessarem fronteiras nacionais e internacionais. As fronteiras internas podem referir-se a divisões administrativas entre regiões ou áreas rurais e urbanas, dentro de um país, enquanto as internacionais se referem a divisões administrativas entre estados/países. As crianças migrantes são um grupo social distinto daquelas que são deixadas para trás, enquanto, pelo menos um dos pais é um migrante noutro lugar, ou das crianças migrantes que nascem no lugar onde os pais escolheram ficar.

As experiências das crianças migrantes variam tendo em conta diferentes fatores como: idade com que chegam ao local de migração, género, ano de escolaridade antes e depois da migração, se viajam sozinhas ou com pais ou outros membros da família, se viveram separadas dos pais antes da reunificação familiar, estatuto socioeconómico, estatuto legal, sentimentos de pertença ou de discriminação, entre outros. Os motivos da migração têm também impacto nas suas experiências, sendo neste caso, considerados fatores impulsionadores as razões pelas quais abandonaram o lugar de nascença, e fatores de permanência o motivo pelo qual chegaram ao novo destino. A migração pode ser explicada por motivos económicos, políticos, ambientais, educativos ou familiares. Os processos de tomada de decisão - antes, durante e após a viagem de um lugar para o outro - são fundamentais para compreender as experiências das crianças migrantes. De acordo com a Organização Internacional para as Migrações - OIM, a estimativa global mais recente aponta para cerca de 31 milhões de crianças que se descolaram forçadamente até ao final de 2018 e, destas, "existem aproximadamente 13 milhões de crianças refugiadas, 936.000 com pedido de asilo, e 17 milhões de crianças forçadas a deslocar-se dentro dos seus próprios países" (IOM, 2020, p.6).

As situações mais dramáticas são enfrentadas por crianças não acompanhadas ou que viajam com os seus pais por rotas migratórias irregulares e inseguras, em que se arriscam a serem separadas deles, serem detidas, sofrerem processos de deportação, tráfico humano, ou mesmo, num cenário pior, tornarem-se crianças migrantes desaparecidas. Diferentes instituições 
internacionais, como a OIM, têm reportado violações dos direitos das crianças migrantes em publicações específicas como o Fatal Journeys Volume 4: Missing Migrant Children (IOM, 2019). Em 2020, o relator principal para os direitos humanos dos migrantes apresentou na Assembleia Geral das Nações Unidas um relatório para a erradicação da detenção de crianças migrantes e a promoção de um cuidado adequado na sua receção, de modo a promover os seus direitos humanos. O Comité para os Direitos da Criança é um outro instrumento internacional a que se pode recorrer no caso de violação de direitos. No final de 2020, três em cada quatro casos pendentes no Comité relacionavam-se com violação de direitos de crianças não acompanhadas (22 em 62) ou de crianças migrantes que ficam com, pelo menos, um dos progenitores (23 em 62), que arriscam deportação, detenção ou retirada do seu estatuto legal no país de residência. As crianças migrantes que fazem uma viagem segura desde o seu país de origem enfrentam novos desafios quando vão viver para um novo destino, entre eles, acesso à educação, participação, cuidados de saúde, discriminação, racismo e xenofobia, acesso a autorizações legais de permanência e à cidadania, entre outros. Para ilustrar esses desafios em diferentes contextos de acolhimento, apresentam-se contributos da China e EUA.

$\mathrm{Na}$ China, a realidade das crianças migrantes é uma consequência de migrações de grande escala de meio rural para urbano, dentro do país. De acordo com o relatório da População Infantil na China, publicado em 2015 pela Unicef, e com base numa amostra de $1 \%$ da população nacional, existiam nesse ano 34,3 milhões de crianças migrantes. Tal como os seus pais, as crianças devem completar um registo local de residência, chamado HuKou, de modo a terem acesso pleno à educação pública, serviços de saúde e outros benefícios sociais. Em 2013, cerca de 20 milhões de crianças com idades entre os 6 e os 14 anos não podiam frequentar escolas públicas uma vez que não eram migrantes HuKou (Chen \& Feng, 2013) e, por esse motivo, eram inscritas em escolas privadas para migrantes, o que tem impactos negativos nas suas conquistas educacionais (Chen \& Feng, 2013).

Nos Estados Unidos, e segundo Rumbaut (2004), os resultados educacionais das crianças diferem de acordo com o país de origem e idade em que migraram. De entre as crianças nascidas num país distinto, o autor introduziu uma distinção entre a geração 1.25 , para os que chegaram com idades entre os 13 e os 17 anos, durante a adolescência, a geração 1.5, para os que chegaram com idades entre os 6 e os 12 anos, durante a escola primária, e a geração 1.75, para aqueles com idades entre os 6 e os 12 anos, durante o pré-escolar e o primeiro ciclo do ensino básico. A idade de migração terá 
diferentes impactos nas memórias e sentimentos de pertença em relação ao país de origem, nas experiências educativas, de socialização e de aprendizagem da língua dos países de acolhimento. Das mencionadas, a geração 1.25 é aquela que tem conquistas educativas mais baixas.

Independentemente do contexto de acolhimento (China ou EUA) e o tipo de migração (interna ou internacional), as crianças migrantes enfrentam desafios semelhantes no campo da educação, dependendo de diferentes fatores, como a idade à chegada e o seu estatuto legal. Para os proteger, Bhabha (2009), da Universidade de Harvard, apela à implementação dos direitos das crianças, considerando: "os direitos das crianças são direitos humanos, mas necessitam de muito mais pensamento, esforço e vontade política para funcionarem como as ferramentas que estão destinadas a ser" (p.450).

\section{Migrant Children}

Migrant children are defined as children under 18 years old, who live in a different region or country from their place of birth, after they have crossed internal or international borders. Internal borders can refer to administrative divisions between regions or rural and urban areas within a country, while international borders refer to administrative divisions between state-countries. Migrant children are a different social group from the ones who are left behind while at least one of their parents is a migrant elsewhere, or the children of migrants who are born in the place where their parents decided to settle.

The experiences of migrant children vary according to different factors, such as: age when they arrive at their place of migration, gender, year of education before and after migration, whether they travel alone or with their parents or other family members, whether they have lived apart from their parents before family reunification, socioeconomic status, legal status, feelings of belonging or discrimination, among others. The reasons for migration also have an impact on their experiences. In this case, push factors refer to the reasons why they left their place of birth, while pull factors refer to the reasons why they arrived at their new destination. Migration can be explained by economic, political, environmental, study or family reasons. The decision-making processes - before, during and after their journey to travel from one place to another - are fundamental to understanding the experiences of migrant children. According to the International Organization for Migration (IOM), the most recent global estimate indicates that 
nearly 31 million children had been forcibly displaced at the end of 2018 . Out of these: "There are approximately 13 million child refugees, 936,000 asylum-seeking children, and 17 million children who have been forcibly displaced inside their own countries" (IOM, 2020, p.6).

The most dramatic situations are faced by unaccompanied children or children who travel with their parents through irregular and unsafe migratory routes. In those cases, they risk being separated from their parents, falling into detention, suffering from deportation, human-trafficking, or even worse if they become missing migrant children. International Organizations such as the IOM have reported rights violations of migrant children, though specific publications like Fatal Journeys Volume 4: Missing Migrant Children (IOM, 2019). In 2020, at the General Assembly of the United Nations the Special Rapporteur on the human rights of migrants presented a report on Ending immigration detention of children and providing adequate care and reception for them, to promote and protect their human rights. The Committee on the Rights of the Child is another international instrument to invoke in the cases of rights violation. At the end of 2020, three out of four pending cases before the Committee were related to rights violation in the cases of unaccompanied children (22 out of 62) or migrant children who stay with at least one of their parents (23 out of 62), who risk deportation, detention, or withdrawal of their legal status in their country of residence.

Migrant children who make a safe journey from their place of birth, face new challenges once they are living at their new destination. Those challenges include access to education, participation, healthcare, discrimination, racism, and xenophobia, the access to legal permission to remain and to citizenship, among others. To illustrate those challenges in different receiving contexts, contributions from China and the United States will be presented.

In China, the reality of migrant children is a consequence of rural-to-urban large-scale migrations of Chinese workers, within the country. According to the report Population Status of Children in China, published by UNICEF in 2015, and based on the 1\% National Population Sample Survey, migrant children were 34,3 million in 2015. Like their parents, to have full access to public education, healthcare, and other social benefits where they live, migrant children must complete a local household registration, called HuKou. In 2013, approximately 20 million children aged between 6 and 14 could not attend public schools because they were non-HuKou migrants (Chen \& Feng, 2013). For this reason, they enrol in private schools for migrants, and 
this orientation has a negative impact on educational attainments (Chen \& Feng, 2013).

In the United States, according to Rumbaut (2004), the educational outcomes of children are different according to the country of origin and the age of migration. Assessing people born in another country he introduced a distinction between generation 1.25, for those who arrived between 13 and 17 years old, during adolescence, generation 1.5, for those who arrived between 6 and 12, during primary school, and generation 1.75, for those who arrived between 0 and 5, during pre- and elementary school. The age of migration will have a different impact on memories and feelings of belonging to the country of origin, the educational experience, socialization, and the learning of the language of the receiving countries. Among the three generations mentioned, generation 1.25 has the lowest educational achievement.

Regardless of the place of migration (China or the United States) and the type of migration (internal or international), migrant children face similar challenges in the field of education, depending on different factors, like their age on arrival or their legal status. To protect them, Bhabha (2009), from the University of Harvard, appeals to the implementation of children's rights, stating: "Children's rights are human rights, but they need much more thought, effort, and political will to function as the tools they were designed to be." (p.450)

\section{Referências / References}

Bhabha, J. (2009). Arendt's children: Do today's migrant children have a right to have rights. Human Rights Quarterly, 31(2), 410-451.

Chen, Y. \& Feng, S. (2013). Access to public schools and the education of migrant children in China. China Economic Review, 26, 75-88.

IOM (2020). World Migration Report 2020. Available online. https://publications.iom.int/system/ files/pdf/wmr_2020.pdf

Rumbaut, R. (2004). Ages, Life Stages, and Generational Cohorts: Decomposing the Immigrant First and Second Generations in the United States. International Migration Review, 38 (3), 1160-1205 . 